\title{
Preventive effect of fermented Maillard reaction products from milk proteins in cardiovascular health
}

\author{
N. S. Oh, ${ }^{*} \dagger$ H. S. Kwon,† H. A. Lee, ${ }^{*}$ J. Y. Joung, ${ }^{*}$ J. Y. Lee, ${ }^{*}$ K. B. Lee, ${ }^{*}$ Y. K. Shin, ${ }^{*}$ S. C. Baick, ${ }^{*}$ M. R. Park,† \\ Y. Kim,‡ K. W. Lee,† and S. H. Kim† ${ }^{1}$ \\ ${ }^{*} R \& D$ Center, Seoul Dairy Cooperative, Ansan, Kyunggi 425-839, South Korea \\ †Division of Food Bioscience and Technology, College of Life Science and Biotechnology, Korea University, Seoul 136-701, South Korea \\ łBK21 Plus Graduate Program, Department of Animal Science and Institute of Rare Earth for Biological Application, Chonbuk National University, \\ Jeonju, 561-756, South Korea
}

\begin{abstract}
The aim of this study was to determine the dual effect of Maillard reaction and fermentation on the preventive cardiovascular effects of milk proteins. Maillard reaction products (MRP) were prepared from the reaction between milk proteins, such as whey protein concentrates (WPC) and sodium caseinate (SC), and lactose. The hydrolysates of MRP were obtained from fermentation by lactic acid bacteria (LAB; i.e., Lactobacillus gasseri $\mathrm{H} 10$, L. gasseri H11, Lactobacillus fermentum $\mathrm{H} 4$, and L. fermentum $\mathrm{H} 9$, where humanisolated strains were designated $\mathrm{H} 1$ to H15), which had excellent proteolytic and 1,1-diphenyl-2-picrylhydrazyl $(\mathrm{DPPH})$ radical scavenging activities $(>20 \%)$. The antioxidant activity of MRP was greater than that of intact proteins in assays of the reaction with $2,2^{\prime}$-azinobis (3-ethylbenzothiazoline-6-sulfonic acid) diammonium salt and trivalent ferric ions; moreover, the effect of MRP was synergistically improved by fermentation. The Maillard reaction dramatically increased the level of antithrombotic activity and 3-hydroxy-3-methylglutaryl-CoA reductase (HMGR) inhibitory effect of milk proteins, but did not change the level of activity for micellar cholesterol solubility. Furthermore, specific biological properties were enhanced by fermentation. Lactobacillus gasseri H11 demonstrated the greatest activity for thrombin and HMGR inhibition in Maillardreacted WPC, by 42 and 33\%, respectively, whereas hydrolysates of Maillard-reacted SC fermented by $L$. fermentum H9 demonstrated the highest reduction rate for micellar cholesterol solubility, at $52 \%$. In addition, the small compounds that were likely released by fermentation of MRP were identified by size-exclusion chromatography. Therefore, MRP and hydrolysates of fermented MRP could be used to reduce cardiovascular risks.
\end{abstract}

Received November 17, 2013

Accepted February 18, 2014.

${ }^{1}$ Corresponding author: saehkim@korea.ac.kr
Key words: prevention of cardiovascular diseases, antioxidant activity, lactic acid bacteria, Maillard reaction, milk protein

\section{INTRODUCTION}

Cardiovascular diseases (CVD), which are currently an issue in both adults and children and are often caused by unhealthy diet, stress, and lack of exercise (i.e., lifestyle), have been the leading cause of death worldwide in recent years, with consistent increases in mortality year over year. Many of the major risk factors for coronary disease have been identified, and researchers are studying different modifiable factors that may influence CVD. Several studies have focused on the effects of various biological or chemical compounds on CVD, such as inhibition of angiotensin-converting enzyme (ACE), reduction of cholesterol solubility, fibrinolytic activity, antithrombotic activity, and antioxidant activity, among others (Houston, 2005; Chung et al., 2008; Miguel et al., 2009).

Under oxidative stress, oxidative modifications of low density lipoprotein occur, leading to atherosclerosis. Free radicals generated from reduction of oxygen may cause cellular damage and contribute to atherosclerosis, arthritis, diabetes, and carcinoma (Halliwell, 1994; Aviram, 2000). The major effect of antioxidants is to prevent the formation of oxidized low density lipoprotein and severe tissue injury. Thrombin is one of the major pathogenic factors in CVD. It is a multifunctional protease generated at sites of vascular injury that acts to trigger fibrin formation, platelet aggregation, and chemotaxis for monocytes, fibroblasts, and vascular smooth muscle cells (Coughlin, 1994). However, excessive generation of fibrin due to activation of the coagulation cascade by thrombin leads to thrombosis, triggering blockage of a vessel and causing various cardiovascular disorders (leading to CVD). Hypercholesterolemia (elevated serum cholesterol) also plays a major role as it leads over time to atherosclerosis and CVD. Serum cholesterol is produced both through 
Table 1. Chemical composition (means \pm SD) of whey protein concentrate (WPC) and sodium caseinate (SC) used in this study

\begin{tabular}{lrr}
\hline Component & \multicolumn{1}{c}{ WPC } & \multicolumn{1}{c}{ SC } \\
\hline Moisture (\%) & $4.6 \pm 0.2$ & $4.0 \pm 0.3$ \\
Protein (\% dry basis) & $97.7 \pm 1.0$ & $97.8 \pm 0.8$ \\
Fat (\%) & $0.3 \pm 1.0$ & $1.0 \pm 0.3$ \\
Ash (\%) & $1.9 \pm 0.3$ & $3.7 \pm 0.2$ \\
Lactose (\%) & $7.66 \pm 0.1$ & $0.14 \pm 0.2$ \\
\hline
\end{tabular}

hepatic cholesterol synthesis, the rate of which is controlled by 3-hydroxy-3-methylglutaryl-CoA reductase (HMGR), and through intestinal cholesterol uptake. Many studies have been performed in which the control of serum cholesterol levels via HMGR inhibition or suppression of cholesterol uptake through reduction of cholesterol solubility have been evaluated (Daniel et al., 2003; Ngamukote et al., 2011; Duangjai et al., 2013).

Milk proteins have many important health benefits and hold considerable nutritional value. Additionally, they are precursors of diverse bioactive compounds that can be released by enzymatic hydrolysis during food processing (including intestinal digestion and the fermentation of milk). The bioactive peptides derived from milk proteins may have antioxidant, immunomodulating, antithrombotic, antihypertensive, and antibacterial properties (Meisel, 1997; Gobbetti et al., 2000; Smacchi and Gobbetti, 2000). In particular, Maillard reaction products (MRP), which are produced by reactions between carbonyl and amine groups, not only produce food characteristics such as aroma, color, flavor, and texture (Fayle and Gerrard, 2002) but also increase the antioxidant activity of milk proteins (McGookin and Augustin, 1991; Chevalier et al., 2001). Moreover, our group has reported that the biological characteristics and antioxidant activity of milk proteins were improved by the combination of the Maillard reaction and enzymatic hydrolysis (with commercial proteases; Oh et al., 2013).

Few studies exist on the potential preventive cardiovascular effects (reduction of cholesterol uptake, inhibition of thrombin and HMGR, fibrinolytic activity) of milk-derived compounds. Therefore, the qualities of MRP fermented by lactic acid bacteria (LAB) were studied. Furthermore, the aim of this study was to determine the effects of MRP and fermented MRP on antioxidant activity, antithrombotic activity, HMGR inhibition activity, and cholesterol reduction activity for reduction of cardiovascular risks.

\section{MATERIALS AND METHODS}

\section{Chemicals}

Whey protein concentrate-80 (WPC) and sodium caseinate (SC) were obtained from Davisco Foods
International Inc. (Le Sueur, MN) and Kerrygold (Dublin, Ireland), respectively, and their compositions are presented in Table 1. Lactose monohydrate was purchased from Junsei Chemical Co. (Tokyo, Japan). The chemicals, including o-phthaldialdehyde (OPA), 1,1-diphenyl-2-picrylhydrazyl (DPPH), 2,2'-azino-bis (3-ethylbenzothiazoline-6-sulfonic acid) diammonium salt (ABTS), potassium persulfate, 2,4,6-tripyridyl-striazine (TPTZ), L-ascorbic acid, iron (III) chloride hexahydrate, fibrinogen, thrombin, and cholesterol used in this study were purchased from Sigma Chemical Co. (St. Louis, MO). Disodium monophosphate, monosodium phosphate, and iron (II) sulfate heptahydrate were from Showa Chemicals (Osaka, Japan). All chemicals used were of analytical grade.

\section{Preparation of MRP from Milk Proteins}

Whey protein concentrate, SC, and lactose were dissolved in $0.1 \mathrm{M}$ sodium phosphate buffer $(\mathrm{pH} 7.4)$ at a 1:5 (wt/wt) ratio of protein $(10 \mathrm{mg})$ and sugar (50 $\mathrm{mg}$ ). The reaction was allowed to proceed with shaking at $60 \mathrm{rpm}$ in a water bath at $55^{\circ} \mathrm{C}$ for $1 \mathrm{~d}$. The $\mathrm{pH}$ was not controlled during the reaction. Then, reaction mixtures were extensively dialyzed against $0.1 \mathrm{M}$ sodium phosphate buffer ( $\mathrm{pH} 7.4) 3$ times within $24 \mathrm{~h}$ and were lyophilized.

\section{Fermentation of MRP from WPC-Lactose and SC-Lactose}

A total of 20 strains of lactic acid bacteria strains isolated from humans and plants (human-isolated strains were designated $\mathrm{H} 1$ to $\mathrm{H} 15$; plant-isolated strains were designated P1 to P5)in this study were obtained from the Food Microbiology Laboratory, Division of Food Bioscience and Technology, Korea University (Seoul, Korea). All strains were activated 3 times successively in de Man, Rogosa, and Sharpe (MRS) broth (Difco Laboratories, Detroit, MI) at $37^{\circ} \mathrm{C}$ for $18 \mathrm{~h}$ before use. All stock cultures were maintained at $-80^{\circ} \mathrm{C}$ with sterile $50 \%$ (vol/vol) glycerol as a cryoprotectant. The strains were subcultured 3 times before use. Fermentation of MRP from WPC-lactose and SC-lactose was performed in MRP solution (Table 2). Bacterial cells $\left(10^{9} \mathrm{cfu} / \mathrm{mL}\right)$ were inoculated into MRP solution and incubated at $37^{\circ} \mathrm{C}$. Samples were withdrawn after $12,24,36$, and 48 h of fermentation and were adjusted to $\mathrm{pH} 7.5$ with $1 \mathrm{~N}$ $\mathrm{NaOH}$. Samples were then centrifuged at 2,000 $\times g$ for $30 \mathrm{~min}$, and the supernatants were collected.

\section{Proteolytic Activity}

Proteolytic activity was measured according to the method described by Nielsen et al. (2001) using the 
OH ET AL.

Table 2. Media for fermentation used in this study (in $\mathrm{g} / \mathrm{L}$ of distilled water)

\begin{tabular}{|c|c|c|c|}
\hline \multirow[b]{2}{*}{ Ingredient } & \multicolumn{3}{|c|}{ Fermentation media $^{1}$} \\
\hline & Modified MRS & MRP solution & MRP-THIO \\
\hline Dextrose & 20 & 20 & 20 \\
\hline Beef extract & - & - & - \\
\hline Proteose peptone No. 3 & 0.1 & - & 1.0 \\
\hline Yeast extract & - & - & 1.0 \\
\hline Sodium acetate & 5.0 & - & 5.0 \\
\hline Ammonium citrate & - & - & 2.0 \\
\hline Dipotassium phosphate & 2.0 & - & 2.0 \\
\hline Magnesium sulfate & 0.1 & - & 0.1 \\
\hline Manganese sulfate & 0.05 & - & 0.05 \\
\hline Tween 80 & 1.0 & - & 1.0 \\
\hline Maillard reaction products (MRP) & 30 & 30 & 30 \\
\hline Sodium thioglycolic acid & - & - & 0.2 \\
\hline Oxgall & - & - & 0.3 \\
\hline
\end{tabular}

OPA method with slight modification. The strains were inoculated into modified MRS (mMRS) medium (Table 2) containing milk proteins and incubated at $37^{\circ} \mathrm{C}$ for $48 \mathrm{~h}$. Then, $200 \mu \mathrm{L}$ of incubated mMRS was mixed with $600 \mu \mathrm{L}$ of $110 \mathrm{mM}$ TCA. After centrifugation of the mixture at $2,000 \times g$ for $30 \mathrm{~min}, 10 \mu \mathrm{L}$ of supernatant was reacted with $180 \mu \mathrm{L}$ of OPA reagent at $37^{\circ} \mathrm{C}$ for $30 \mathrm{~min}$. The absorbance was measured with a Synergy H1 plate reader (Bio-Tek Instruments Inc., Winooski, VT) at $340 \mathrm{~nm}$. The degree of proteolysis was determined as the difference between optical density (OD) values of fermented mMRS and that of nonfermented mMRS.

\section{Antioxidant Activity}

Determination of DPPH Radical Scavenging Activity. Determination of the radical scavenging properties of fermented MRP followed the method described by Blois (1958) but slightly modified. An aliquot of sample $(100 \mu \mathrm{L})$ was added to $100 \mu \mathrm{L}$ of 200 $\mu M$ DPPH in ethanol. The solution was then mixed vigorously and allowed to stand at $37^{\circ} \mathrm{C}$ in the dark for $30 \mathrm{~min}$. The absorbance of the solution was measured spectrophotometrically at $517 \mathrm{~nm}$. For comparison, the assay was conducted in the same manner but ascorbic acid was added instead of sample solution (control). The DPPH scavenging activity (\%) was calculated from the equation

$$
\begin{aligned}
& D P P H \text { radical scavenging activity }(\%) \\
& =\frac{O D_{\text {control }}-O D_{\text {sample }}}{O D_{\text {control }}} \times 100 .
\end{aligned}
$$

Ferric-Reducing Antioxidant Power Assay. The reducing ability of fermented MRP was measured using the ferric-reducing antioxidant power (FRAP) assay (Benzie and Strain, 1996). The FRAP reagent was prepared with $0.3 \mathrm{M}$ sodium acetate buffer ( $\mathrm{pH} 3.6$ ), 10 $\mathrm{m} M$ TPTZ in $40 \mathrm{~m} M \mathrm{HCl}$, and $20 \mathrm{mM} \mathrm{FeCl}_{3} \cdot 6 \mathrm{H}_{2} \mathrm{O}$ in a ratio of 10:1:1 (vol/vol/vol). Six microliters of sample was mixed with $180 \mu \mathrm{L}$ of freshly prepared FRAP reagent and incubated at $37^{\circ} \mathrm{C}$ for $30 \mathrm{~min}$; then, the absorbance of mixture was read at $562 \mathrm{~nm}$. Ascorbic acid was used as a positive control. The FRAP value was calculated based on an $\mathrm{Fe}_{2} \mathrm{SO}_{4}$ standard curve.

Determination of ABTS Radical Scavenging Activity. The ABTS radical scavenging activity of fermented MRP was evaluated according to the method described by Re et al. (1999). The ABTS solution prepared from $7 \mathrm{~m} M$ ABTS and $2.45 \mathrm{~m} M$ potassium persulfate was diluted with deionized water to an approximate absorbance of 1.4 at $734 \mathrm{~nm}$. Twenty microliters of sample was added to $180 \mu \mathrm{L}$ of diluted ABTS solution and kept in the dark for 6 min at $25^{\circ} \mathrm{C}$ after shaking. Then, the absorbance of the mixture was measured at $734 \mathrm{~nm}$. Ascorbic acid was used as a positive control. The percentage of ABTS scavenging activity was calculated using the followed equation:

$$
\begin{aligned}
& A B T S \text { radical scavenging activity }(\%) \\
& =\frac{O D_{\text {control }}-O D_{\text {sample }}}{O D_{\text {control }}} \times 100 .
\end{aligned}
$$

The results were reported as the concentration of sample required to scavenge $50 \%$ of ABTS radical $\left(\mathbf{I C}_{50}\right)$.

\section{Thrombin Inhibition Assay}

The ability to inhibit thrombin was measured according to Yang et al. (2007), with minor modifications. Fi- 
brinogen, thrombin, and heparin (as a positive control) were all dissolved in $0.05 M$ Tris- $\mathrm{HCl}$ buffer $(\mathrm{pH} 7.2)$ containing $0.12 \mathrm{mM} \mathrm{NaCl} ; 0.2 \%$ (wt/vol) fibrinogen solution $(140 \mu \mathrm{L})$ and $40 \mu \mathrm{L}$ of sample were added into the plate well and mixed. Next, $10 \mu \mathrm{L}$ of thrombin solution $(20 \mathrm{IU} / \mathrm{mL})$ was added to the well to start the reaction of thrombin-catalyzed coagulation of fibrinogen. The absorbance of the sample was read at $405 \mathrm{~nm}$ at $37^{\circ} \mathrm{C}$ with a kinetic program of every minute up to $10 \mathrm{~min}$. Heparin $(100 \mathrm{IU} / \mathrm{mL})$ and distilled water were used as a positive and negative control, respectively. The inhibitory effect was calculated using followed equation:

$$
\begin{aligned}
& \text { Thrombin inhibition rate }(\%) \\
& =\left(\frac{\Delta O D_{405 \mathrm{~nm}, \text { negative control }}-\Delta O D_{405 \mathrm{~nm}, \text { sample }}}{\Delta O D_{405 \mathrm{~nm}, \text { negative control }}}\right) \times 100 .
\end{aligned}
$$

\section{HMG-CoA Reductase Inhibition Assay}

The ability to inhibit 3-hydroxy-3-methylglutarylCoA reductase (HMGR) was measured by using HMG-CoA reductase assay kit (Sigma Chemical Co.). First, $180 \mu \mathrm{L}$ of assay buffer, $2 \mu \mathrm{L}$ of sample or pravastatin (as a positive control), nicotinamide adenine dinucleotide phosphate (NADPH), and HMG-CoA were added into the plate well, mixed vigorously, and incubated in $37^{\circ} \mathrm{C}$ for $10 \mathrm{~min}$. Then, HMGR was added to the well to start the oxidation of NADPH by the catalytic subunit of HMGR in the presence of the substrate HMG-CoA. After a 10 -min incubation at $37^{\circ} \mathrm{C}$, the absorbance was read at $340 \mathrm{~nm}$. For comparison, activity-blank and blank were conducted in the same manner, but for blank, HMGR was not added. The inhibitory effect was calculated using following equation:

$$
\begin{aligned}
& \text { HMGR inhibition rate }(\%) \\
& =\left(\frac{\Delta O D_{340 \mathrm{~nm}, \text { activity-blank }}-\Delta O D_{340 \mathrm{~nm}, \text { sample }}}{\Delta O D_{340 \mathrm{~nm}, \text { activity-blank }}-\Delta O D_{340 \mathrm{~nm}, \text { blank }}}\right) \times 100 .
\end{aligned}
$$

\section{Cholesterol Reduction Activity}

The cholesterol reduction assay was performed by the method of Kimoto et al. (2002) with slight modification. Freshly prepared broth supplemented with $0.2 \%$ sodium thioglycolic acid as an oxygen scavenger and $0.3 \%$ oxgall as a bile salt was prepared (MRP-THIO broth; Table 2). A filter-sterilized cholesterol solution $(10 \mathrm{mg} / \mathrm{mL}$ in ethanol) was added to the broth at a final concentration of $100 \mu \mathrm{g} / \mathrm{mL}$. The broth was inoculated with $1 \%$ bacterial cells and incubated in $37^{\circ} \mathrm{C}$ for $20 \mathrm{~h}$. After centrifugation at $22,825 \times g$ for $15 \mathrm{~min}$ to remove the cells, the supernatant was used to determinate the amount of cholesterol by using the colorimetric method of Rudel and Morris (1973). Two milliliters of sample and $3 \mathrm{~mL}$ of $97 \%$ ethanol were added to a clean tube, followed by $2 \mathrm{~mL}$ of $50 \%$ potassium hydroxide, and the tube was mixed thoroughly. The mixture was heated for $10 \mathrm{~min}$ in $60^{\circ} \mathrm{C}$ water bath with sealing and, after cooling, $5 \mathrm{~mL}$ of hexane was dispensed into the tube. After mixing thoroughly, the tube was allowed to stand for phase separation. Then, $2.5 \mathrm{~mL}$ of the hexane layer was transferred into another clean tube and evaporated at $60^{\circ} \mathrm{C}$ under flow of nitrogen gas. Four milliliters of OPA reagent $(0.55 \mathrm{mg}$ of OPA per $\mathrm{mL}$ of glacial acetic acid) was added to the tube and allowed to stand at room temperature for $10 \mathrm{~min}$; then, $2 \mathrm{~mL}$ of concentrated sulfuric acid was pipetted slowly down the inside of the tube. The tube was immediately mixed vigorously and left to stand at room temperature for 10 min; then, absorbance was read at $550 \mathrm{~nm}$. The amount of cholesterol was calculated from a standard curve prepared using cholesterol $(0,50,100,150$, and 200 $\mu \mathrm{g} / \mathrm{mL}$ ). The cholesterol reduction rate was calculated using the equation

$$
\begin{aligned}
& \text { Cholesterol reduction rate }(\%) \\
= & \left(\frac{O D_{550 \mathrm{~nm}, \text { control }}-O D_{550 \mathrm{~nm}, \text { sample }}}{O D_{550 \mathrm{~nm}, \text { control }}}\right) \times 100 .
\end{aligned}
$$

\section{Size-Exclusion Chromatography}

Proteins were separated from milk proteins and MRP by size-exclusion-fast protein liquid chromatography (SEC-FPLC) using a Superose 12 10/300 GL column with a UV detector operating at $280 \mathrm{~nm}$ (GE Healthcare Bio-Sciences AB, Björkgatan 30, Sweden). Small molecular sized compounds $(\leq 7,000 \mathrm{Da})$, such as peptides and amino acids, of MRP and fermented MRP were analyzed by using a Superdex Peptide 10/300 GL column with a UV detector at $214 \mathrm{~nm}$ (GE Healthcare Bio-Sciences AB). The analytical conditions of the FPLC system were as follows: flow rate $=0.5 \mathrm{~mL} /$ min, eluent $=50 \mathrm{~m} M$ phosphate with $0.15 M \mathrm{NaCl}$ $(\mathrm{pH} 7.0)$, and injection volume $=100 \mu \mathrm{L}$. The protein concentration of the sample was determined by using a Synergy H1 plate reader (Bio-Tek Instruments Inc.) with the Take3 microdrop addition. All samples were diluted with distilled water for the same protein concentration and filtered through $0.45-\mu \mathrm{m}$ filters before injection onto the FPLC system.

\section{Bacterial Identification}

Chromosomal DNA from selected 4 LAB strains (Lactobacillus gasseri $\mathrm{H} 10$, L. gasseri $\mathrm{H} 11$, Lactobacillus 
fermentum $\mathrm{H} 4$, and L. fermentum $\mathrm{H} 9$ ) was extracted and the 16S rRNA gene was amplified using universal primers. The PCR primer sequences were as follows: forward primer, 5'-AGAGTTTGATCCTGGCTCAG-3'; reverse primer, 5'-GGTTACCTTTGTTACGACTT-3' (Bioneer, Daejeon, Korea). Amplified products were analyzed by using an ABI 377 automated DNA sequencer (Perkin Elmer, Waltham, MA). Sequence homologies were examined by comparing the obtained sequences with those in the DNA databases (http:// www.ncbi.nlm.nih.gov/BLAST).

\section{Statistical Analysis}

All data were expressed as means \pm standard deviations. Statistical significance for the differences between the groups was assessed using Duncan's multiple range tests, and SAS software (version 9.2; SAS Institute Inc., Cary, NC) was used to perform all statistical tests. Values of $P<0.05$ were considered to indicate a significant difference.

\section{RESULTS AND DISCUSSION}

\section{Screening of LAB Strains for Proteolytic Activity}

The proteolytic activity of LAB strains was determined using an OPA-based spectrophotometric assay that detects released $\alpha$-amino groups from milk proteins (Shihata and Shah, 2000). The extent of proteolysis varied among types of milk proteins and strains (data not shown). Ten strains (H15, P2, H3, H2, H11, H5, H7, H10, H13, and H14) hydrolyzed WPC better than other strains and increased the OD value (up to 0.99 in the case of H15). Five strains (H4, P5, P4, H12, and H9) had greater proteolytic activity than the other strains on SC, equivalent to 0.1 degree of $\mathrm{OD}$ value. Conversely, a few strains (H6, P1, H1, and P3) could not degrade either WPC or SC. In addition, the proteolytic activity on WPC was much higher than that on $\mathrm{SC}$, a finding that might be attributable to structural differences between the proteins. According to Livney (2010), $\beta$-LG, the major whey protein, is a small globular protein folded into a $\beta$-barrel with a 3 -turn $\alpha$-helix on its surface; BSA is a larger globular protein, with a mainly $\alpha$-helical structure. Therefore, WPC might be hydrolyzed by LAB and relatively more $\alpha$-amino groups (compared with that from SC) released from the N-terminal sequence to react with OPA reagent based on the mechanism of the proteolytic assay for measuring $\alpha$-amino acids. The strains showing high proteolytic activity for milk proteins were expected to hydrolyze MRP, and hydrolysates derived from fermentation were expected to have bioactive properties.

\section{Screening of LAB Strains for DPPH Radical Scavenging Activity}

The DPPH radical scavenging activity was evaluated by reacting cell-free supernatants of LAB cultures in MRS medium with stable DPPH free radicals. The DPPH radical scavenging activities of the strains are shown in Figure 1. Almost all of the strains revealed activity levels between 16 and 33\%, except for 2 strains in which the activity was around $8 \%$ (i.e., H13 and H14).

A total of 13 strains were selected through the proteolysis and antioxidation screen tests - 8 strains for WPC and 5 for SC. The MRP from WPC and SC with lactose were fermented by the selected strains, but only 2 strains of each MRP had a $\mathrm{pH}$ value $<4.8$ after fermentation for $48 \mathrm{~h}$ (data not shown). Finally, the selected strains were H10 and H11 for Maillard-reacted WPC (wMRP), and H4 and H9 for Maillard-reacted SC (cMRP). Based on the results from 16S rRNA sequencing, all sequenced strains were identified as either L. gasseri (H10 and H11) or L. fermentum (H4 and H9).

\section{Determination of Antioxidant Activity}

Antioxidant activity was determined by using the DPPH, FRAP, and ABTS assays. Specifically, the DPPH assay measured hydrogen-donating activity, the FRAP assay measured the reducing power of ferric ions, and the ABTS assay examined cation-scavenging activity. The DPPH radical scavenging activities of MRP and fermented MRP are depicted in Figure 2. Maillard reaction products showed lower radical scavenging activity than intact milk proteins, and the effect of fermentation depended on the type of milk proteins and strains. In agreement, a previous study showed that reduction of DPPH decreased during the Maillard reaction of sugars and amino acids (Morales and Jiménez-Pérez, 2001). Hwang et al. (2011) reported that an unheated sugar-cysteine mixture had greater activity than did MRP of sugar-cysteine; this was attributable to the fact that cysteine was an antioxidant with a direct effect on free radicals (Sen, 1999). The change in radical scavenging activity was not shown in wMRP fermented by $L$. gasseri $\mathrm{H} 10$; the effect was actually decreased by L. gasseri $\mathrm{H} 10$, whereas cMRP was changed by the increase in fermentation effect. Comparison with ascorbic acid $(100 \mu \mathrm{g} / \mathrm{mL})$ as a positive control showed 91.6\% scavenging activity (data not shown).

To determine the antioxidant effects of Maillard reaction and fermentation, the FRAP assay was performed to assess another mechanism for antioxidant activity. Ascorbic acid $(100 \mu \mathrm{g} / \mathrm{mL})$, as a positive control, gave a value of $1.31 \pm 0.02 \mathrm{mM} \mathrm{FeSO}{ }_{4} \cdot 7 \mathrm{H}_{2} \mathrm{O}$ equivalents (data not shown). The effects of both wMRP and 


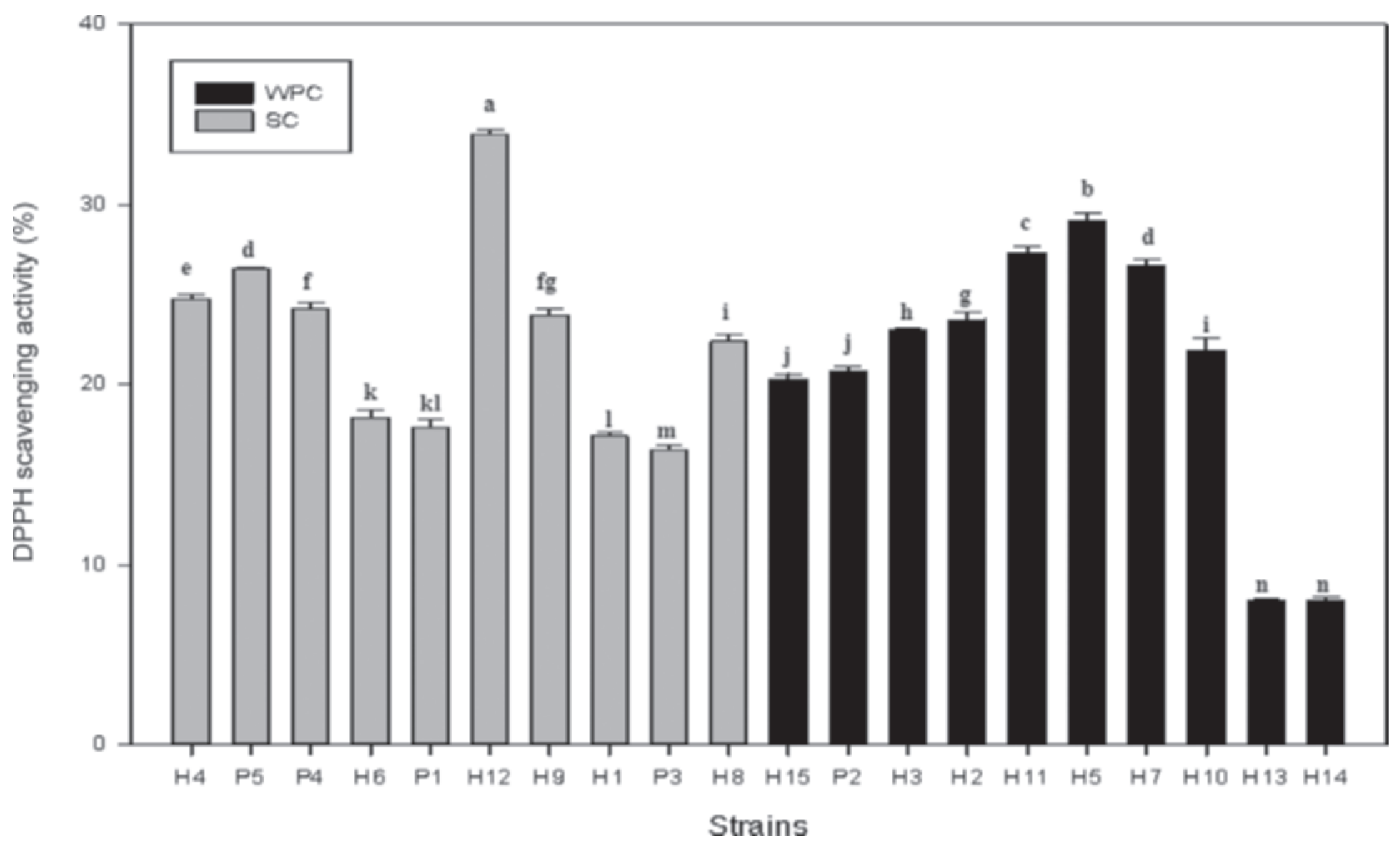

Figure 1. 1,1-Diphenyl-2-picrylhydrazyl (DPPH) radical scavenging activity of various lactic acid bacteria (LAB) strains on whey protein concentrate (WPC) and sodium caseinate (SC). Values are means \pm SD $(\mathrm{n}=3)$; data followed by a different lowercase letter are significantly different $(P<0.05)$.

cMRP were higher than for intact milk proteins, with increases equivalent to 41.2 and $33.0 \mathrm{mM} \mathrm{FeSO} 4 \cdot 7 \mathrm{H}_{2} \mathrm{O}$, respectively (Figure 3). The antioxidant power of MRP gradually increased with increasing fermentation time. Moreover, fermented cMRP showed high antioxidant activity; the highest reducing power was observed for cMRP fermented by L. fermentum $\mathrm{H} 9$ for $48 \mathrm{~h}$, at $0.36 \pm$ $0.02 \mathrm{mM} \mathrm{FeSO} \cdot 7 \mathrm{H}_{2} \mathrm{O}$ equivalents. These results revealed that Maillard reaction and fermentation could have a positive effect on the reducing power of milk proteins.

In addition, all MRP and fermented MRP exhibited high ABTS radical scavenging activity $\left(\mathrm{IC}_{50}\right)$ in a range from $1.20 \pm 0.06$ to $5.10 \pm 0.03 \mathrm{mg} / \mathrm{mL}$ (Figure 4). The ABTS radical scavenging activity was dramatically improved through Maillard reaction, as the $\mathrm{IC}_{50}$ values of wMRP and cMRP were $5.10 \pm 0.03$ and 1.22 $\pm 0.04 \mathrm{mg} / \mathrm{mL}$, respectively; observed values for WPC and $\mathrm{SC}$ were $70.06 \pm 1.05$ and $6.28 \pm 0.02 \mathrm{mg} / \mathrm{mL}$, respectively. Few differences were observed for cMRP by fermentation time, whereas the antioxidant activity of wMRP increased through fermentation. According to the report by Meisel (2005), the antioxidant activity of whey and whey-derived peptides has been linked to cysteine-rich proteins, which promote the synthesis of glutathione, a strong intracellular antioxidant. The $\mathrm{IC}_{50}$ value of ascorbic acid as a positive control was 53.69 $\pm 0.48 \mu \mathrm{g} / \mathrm{mL}$ (data not shown), which indicated that MRP and fermented MRP could contribute to increased radical scavenging activity, although the extent of their contribution was not as great as that of ascorbic acid.
Previously, Gu et al. (2009) reported that hydrolysis of MRP significantly increased their radical scavenging activity and reducing power because MRP could serve as electron donors. Accordingly, the antioxidant activity, as observed in the FRAP and ABTS assays, was significantly higher for MRP than for intact proteins. These results are similar to the results of our earlier study on the antioxidant effects of MRP and their enzymatic hydrolysates (Oh et al., 2013). However, the effect of fermentation was less with respect to antioxidant activity compared with that of enzymatic hydrolysis of MRP, despite the fact that the increased effects of fermentation of MRP indicated that the MRP were hydrolyzed by the proteases released from fermentation.

The 3 assays, which measured antioxidant activity using 3 different mechanisms, demonstrated slight differences in this activity, perhaps because the Maillard reaction and hydrolysis by fermentation disrupted the protein structure, potentially altering or producing new functional properties (Kristinsson and Rasco, 2000). According to the presented results and reports, the Maillard reaction increased antioxidant activity from milk proteins and fermentation enhanced the activity of MRP.

\section{Determination of Antithrombotic Activity}

Antithrombotic peptides have broad application in prevention and treatment of CVD (Silva and Malcata, 

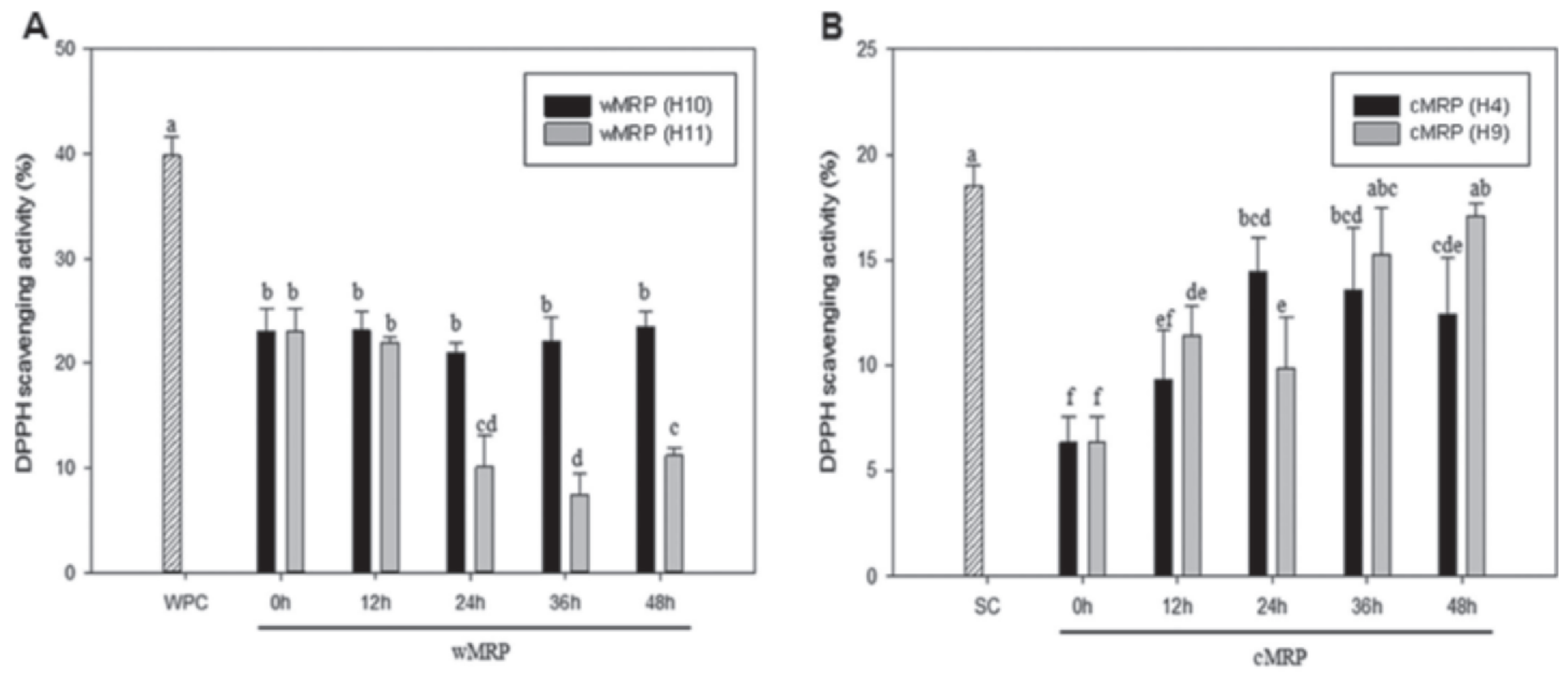

Figure 2. 1,1-Diphenyl-2-picrylhydrazyl (DPPH) radical scavenging activity of (A) whey protein concentrate (WPC) and fermented Maillardreacted WPC (wMRP), and (B) sodium caseinate (SC) and fermented Maillard-reacted SC (cMRP) during fermentation by Lactobacillus gasseri (H10 and H11) and Lactobacillus fermentum (H4 and H9). Values are means \pm SD (n = 3); data followed by a different lowercase letter are significantly different $(P<0.05)$.

2005; Erdmann et al., 2008). The hydrolysates from fermented MRP by the 4 selected LAB strains were investigated for their antithrombotic effects (see Figure 5). Both wMRP and cMRP increased the thrombin inhibition rate compared with intact milk proteins (which did not inhibit thrombin) by $25.47 \pm 0.93$ and
$20.13 \pm 0.56 \%$, respectively. Moreover, fermented MRP exhibited an increased inhibition rate compared with nonfermented MRP, with the exception of fermentation by $L$. fermentum $\mathrm{H} 4$; no results were significantly different according to fermentation time. Among fermented MRP, the greatest activity was observed for wMRP
A

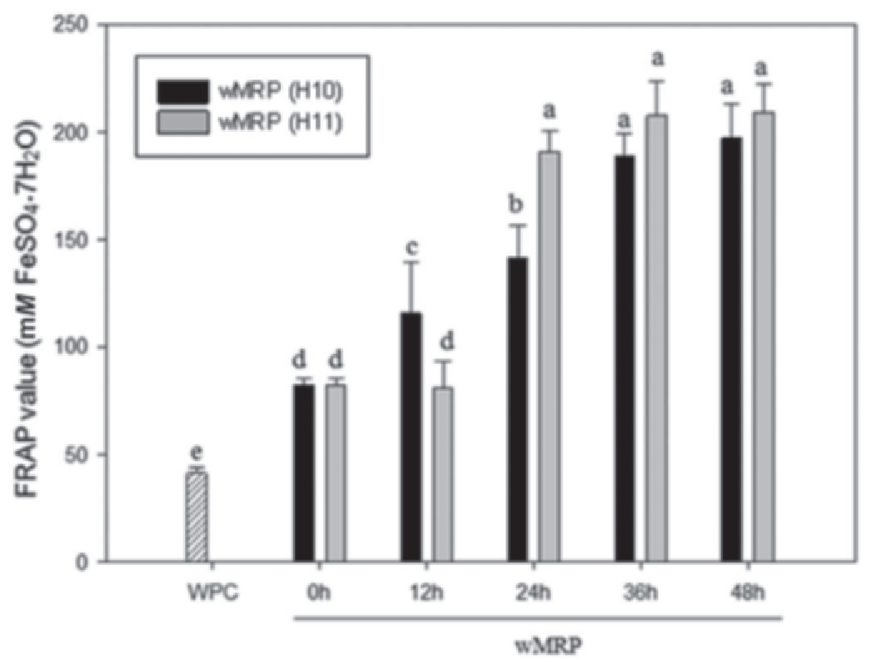

B

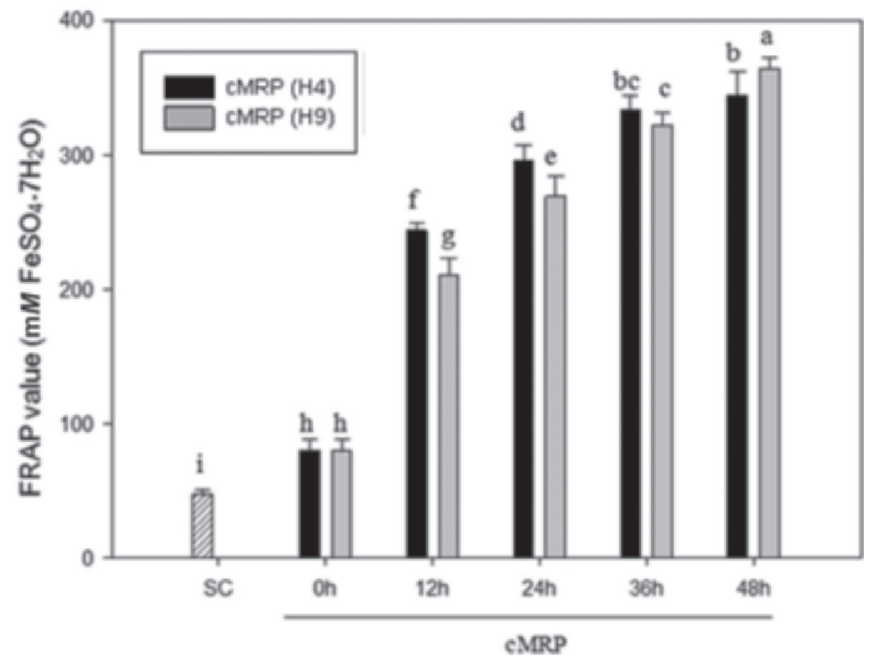

Figure 3. Ferric-reducing antioxidant power (FRAP value) of (A) whey protein concentrate (WPC) and fermented Maillard-reacted WPC (wMRP), and (B) sodium caseinate (SC) and fermented Maillard-reacted SC (cMRP) during fermentation by Lactobacillus gasseri (H10 and H11) and Lactobacillus fermentum (H4 and H9). Values are means $\pm \mathrm{SD}(\mathrm{n}=3)$; data followed by a different lowercase letter are significantly different $(P<0.05)$. 
A

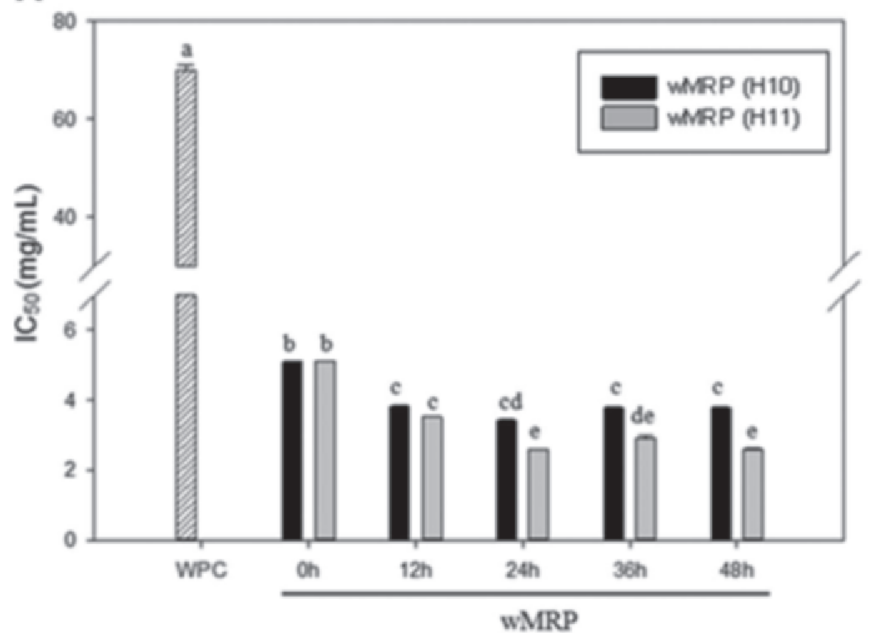

B

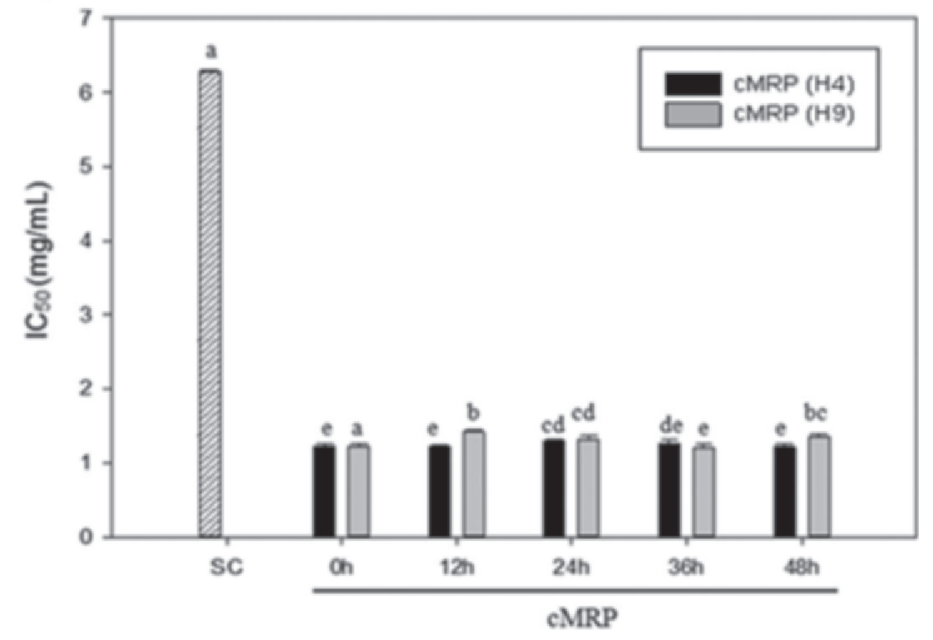

Figure 4. 2,2'-Azino-bis (3-ethylbenzothiazoline-6-sulfonic acid) (ABTS) radical scavenging activity (in $\mathrm{IC}_{50}$, the concentration able to scavenge $50 \%$ of radicals) of (A) whey protein concentrate (WPC) and fermented Maillard-reacted WPC (wMRP), and (B) sodium caseinate (SC) and fermented Maillard-reacted SC (cMRP) during fermentation by Lactobacillus gasseri (H10 and H11) and Lactobacillus fermentum (H4 and H9). Values are means $\pm \mathrm{SD}(\mathrm{n}=3)$; data followed by a different lowercase letter are significantly different $(P<0.05)$.

fermented by L. gasseri H11 (41.78 $\pm 2.22 \%$ inhibition rate). In general, fermented wMRP strains were more effective than fermented cMRP strains for the inhibition of thrombin. In a previous study, peptides derived from lactoferrin, which was included in whey, were shown to inhibit platelet aggregation due to structural similarities to the fibrinogen $\alpha$-chain (Mazoyer et al., 1990). Caseinomacropeptide, the C-terminal fragment of $\kappa$-casein, also shows antithrombotic properties, as it is homologous in position to the $\gamma$-chain of human fibrinogen (Fiat et al., 1989). It is likely that the derivatives of WPC and SC have different modes of action, leading to their distinctly different effects on results. Moreover, the forms of glycoprotein may have the property of thrombin inhibition due to their structure, which is similar to the fibrinogen chain; MRP from reactions between proteins and sugars showed strong antithrombotic effects. In addition, significant molecular similarity exists between milk clotting and blood clotting, which have analogous mechanisms of interaction of $\kappa$-casein with chymosin and fibrinogen with thrombin, respectively (Jollès, 1975). To summarize, our results indicate that the fermented hydrolysates of MRP significantly inhibited thrombin activity.

\section{Determination of HMGR Inhibition Activity}

3-Hydroxy-3-methylglutaryl-CoA reductase is the key enzyme of the mevalonate pathway, which produces cholesterol from HMG-CoA in the hepatic system. Maillard reaction products and fermented MRP were tested to determine HMGR inhibition activities (and, through this, a degree of control over cholesterol lev- els). Maillard reaction and fermentation significantly increased the inhibition rate of HMGR from intact milk proteins, and the effects between fermented wMRP and cMRP were not significantly different (Figure 6). Both wMRP and cMRP increased the HMGR inhibition rate (by 17.6 and $19.6 \%$, respectively) compared with intact milk proteins. In addition, the effect of HMGR inhibition tended to increase with fermentation time, but the difference varied among the strains. In the case of fermented wMRP, the difference of effects between 2 strains was significant. Lactobacillus gasseri H11 showed the greatest activity at $32.97 \pm 0.55 \%$, which is comparable to that of pravastatin (a pharmaceutical product); cMRP fermented by L. fermentum H9 suppressed HMGR activity by $29.52 \pm 1.02 \%$.

The HMGR inhibition effects of milk proteins or their hydrolysates have not been extensively studied; however, plant proteins and sterols have been isolated for investigation of their effects. For example, Chen and Reimer (2009) reported that whey and casein downregulated the expression of the $H M G R$ gene. In another study, consumption of puerarin glycosides in mice was shown to suppress $H M G R$ mRNA levels (Chung et al., 2008). Jesch et al. (2009) noted decreased HMGR mRNA levels by sitosterol. Several mechanisms exist that regulate cholesterol synthesis in the mevalonate pathway (Mehrafarin et al., 2010); among these mechanisms are HMGR inhibition of synthesis by both phosphorylation and antioxidation. The assay in the current study measured the amount of NADPH that could be oxidized by HMGR. The FRAP and ABTS results corresponded with HMGR inhibition results in the present study and supported the mechanism between antioxidation and 
A

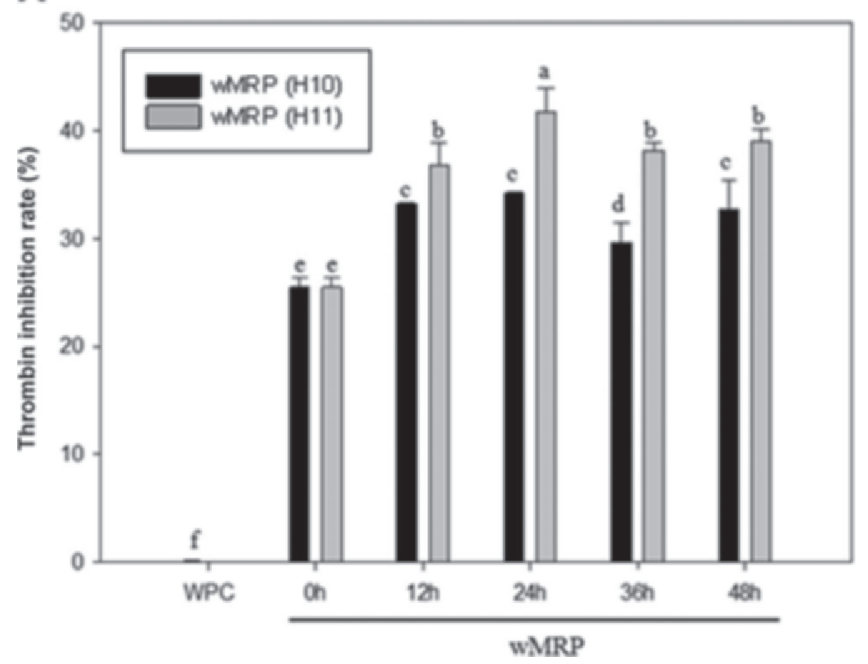

B

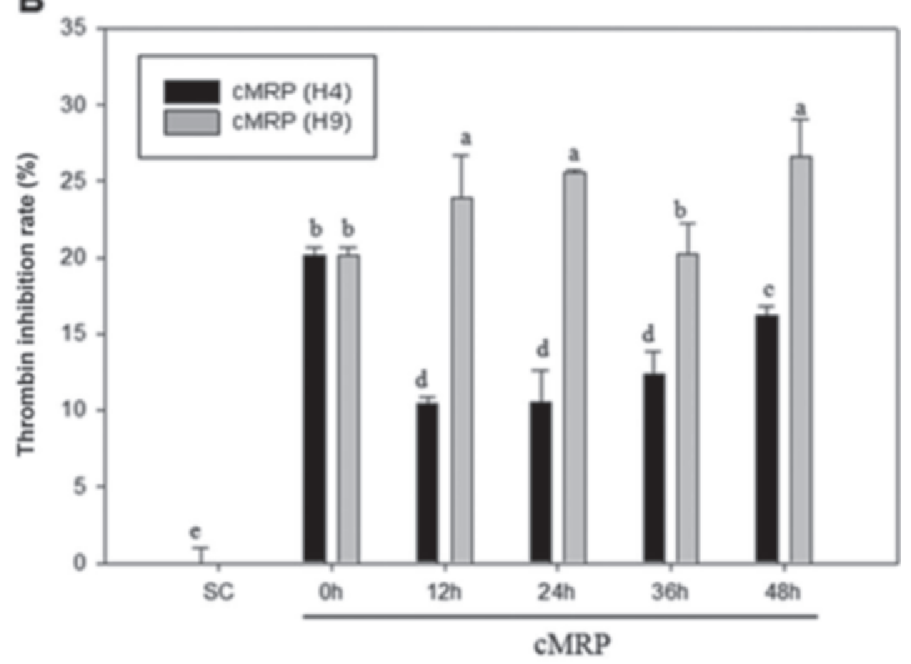

Figure 5. Thrombin inhibition activity of (A) whey protein concentrate (WPC) and fermented Maillard-reacted WPC (wMRP), and (B) sodium caseinate (SC) and fermented Maillard-reacted SC (cMRP) during fermentation by Lactobacillus gasseri (H10 and H11) and Lactobacillus fermentum (H4 and H9). Values are means $\pm \mathrm{SD}(\mathrm{n}=3)$; data followed by a different lowercase letter are significantly different $(P<0.05)$.

HMGR inhibition. As antioxidant activity increased, the effect of thrombin inhibition also increased, due to both the Maillard reaction and fermentation.

\section{Determination of Reduction of Micellar Cholesterol Solubility}

The solubility of micellar cholesterol associated with cholesterol uptake in the intestine was tested for MRP and fermented MRP. The Maillard reaction had no ef- fect on micellar cholesterol solubility of milk proteins, and the amount of cholesterol in cMRP was increased compared with that in SC (Figure 7). Most strains, except for L. fermentum $\mathrm{H} 4$, reduced micellar cholesterol solubility after fermentation of MRP for $48 \mathrm{~h}$. Fermentation by $L$. fermentum H9 dramatically lowered the cholesterol level by $51.85 \pm 1.00 \%$, compared with the initial level by cMRP of $16.23 \pm 1.00 \%$. This assay measures binding to bile acids, which is one of the mechanisms of action for lowering total serum cho-
A

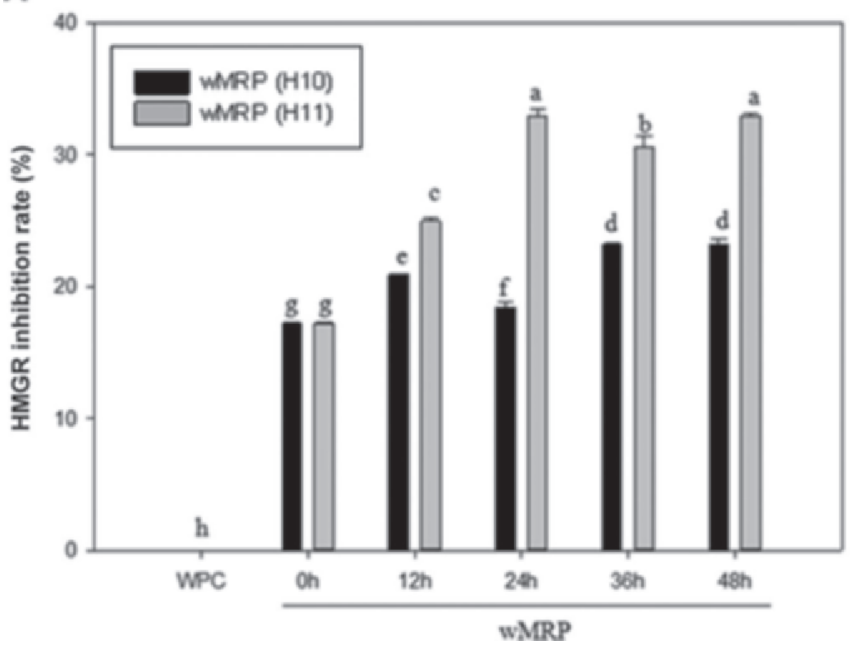

$\mathbf{B}$

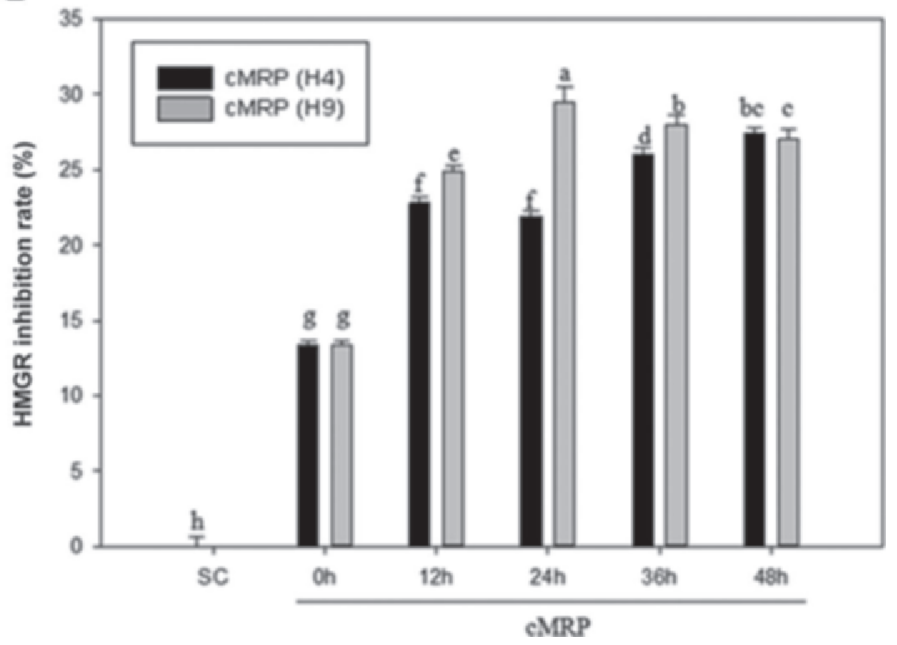

Figure 6. 3-Hydroxy-3-methylglutaryl-CoA reductase (HMGR) inhibition activity of (A) whey protein concentrate (WPC) and fermented Maillard-reacted WPC (wMRP), and (B) sodium caseinate (SC) and fermented Maillard-reacted SC (cMRP) during fermentation by Lactobacillus gasseri (H10 and H11) and Lactobacillus fermentum (H4 and H9). Values are means \pm SD (n $=3$ ); data followed by a different lowercase letter are significantly different $(P<0.05)$. 
lesterol levels. Pak et al. (2005) determined that hydrophobicity is required for biological activity leading to a cholesterol-lowering effect, and the presence of a proline residue seems to be a key component. Moreover, the correlation between hydrophobicity and the capacity to bind to bile acids suggests that peptides with a high bile acid-binding capacity could inhibit the absorption of bile acids in the ileum and decrease serum cholesterol levels (Iwami et al., 1986). As casein contains a high amount of proline and the hydrophobic $\alpha$ - and $\beta$-casein subunits, the cMRP hydrolysates fermented by H9 showed the highest reduction rate of micellar cholesterol solubility. One reason why either of the 2 strains using cMRP had much greater activity might be that the degradation products released by fermentation had different compositions (i.e., different AA). According to some reports (Kritchevsky et al., 1982; Morita et al., 1997), the specific AA composition probably influences serum cholesterol levels. The hydrophobic AA such as Ala, Tyr, Val, Leu, or Lys and peptide size are observed in relation to a decrease in cholesterol absorption and cholesterol micellar solubility (Megías et al., 2009).

Several studies had similar results. For example, in one study, tryptic hydrolysates of casein reduced micellar cholesterol solubility by $20 \%$, and bovine $\beta$-LG hydrolysates showed $38 \%$ reduction activity for solubility (Nagaoka et al., 2001). Zhong et al. (2007) obtained an inhibition rate for micellar cholesterol solubility by soy protein alcalase hydrolysates of $48.6 \%$. Therefore, MRP hydrolysates from milk proteins suppress micellar cholesterol solubility.

\section{Analysis of MRP and Fermented MRP by SEC-FPLC}

Milk proteins and their MRP (10 mg/mL of protein) were loaded on a size-exclusion column with an optimal molecular weight range of 5 to $5,000 \mathrm{kDa}$ to confirm the production of MRP by Maillard reaction from milk proteins. As shown in Figure 8A, BSA (66.5 kDa), $\beta-\mathrm{LG}$ $(18.4 \mathrm{kDa})$, and $\alpha$-LA $(14.2 \mathrm{kDa})$, the main components of WPC, were detected in order of molecular size. The chromatogram shows a noticeable difference between milk proteins and their MRP as the area of peaks $>14$ $\mathrm{kDa}$ was increased. Casein comprises 4 representative caseins (i.e., $\alpha-, \beta-, \gamma$-, and $\kappa$-caseins); however, only 2 main peaks were detected (Figure 8 ) because the caseins are too similar in size to be separated and form as an aggregated micelle. Similar results for casein separation have been reported previously (Chobert et al., 1988). As depicted in Figure 8B, the primary peak of cMRP was notably increased, as was the peak for wMRP. From these results, MRP were confirmed to be produced through Maillard reaction from intact milk proteins. Our earlier study also noted that MRP were produced as higher molecular size bands (in the range of 75 to $245 \mathrm{kDa}$ by SDS-PAGE), in agreement with the present results (Oh et al., 2013).

Furthermore, the fermented hydrolysates of MRP were separated by SEC-FPLC for comparative analysis with nonfermented MRP (Figure 9). The peaks in a retention volume of approximately $17.5 \mathrm{~mL}$ were detected in the chromatograms of fermented MRP by all 4 strains, of which the molecular size was assumed to be above $1.4 \mathrm{kDa}$ (vitamin $\mathrm{B}_{12}$ ). The end products of fermentation by LAB are organic acids, extracellular enzymes, peptides and AA, ethanol, aroma compounds, bacteriocins, exopolysaccharides, and so on. As the MRP from reactions between milk proteins and sugars were fermented, bioactive compounds might have been peptides, AA, and organic acids among the possible end products, or unknown compounds. According to the report by Pihlanto-Leppälä (2000), bioactive peptides usually range from 2 to $20 \mathrm{AA}$ in length and generally exhibit a small molecular size. However, potential preventive cardiovascular effects have rarely been reported, although the antioxidant effects of bioactive peptides have been described. Tezcan et al. (2009) reported that commercial pomegranate juices, which contain organic acids (mainly citric acids and malic acid), showed high antioxidant activity, and sweet cherry juice has been shown to have similar activity (Usenik et al., 2008). Indeed, peaks were found in fermented MRP that were absent in nonfermented MRP; overall, in the current study, we determined that fermented MRP had out-

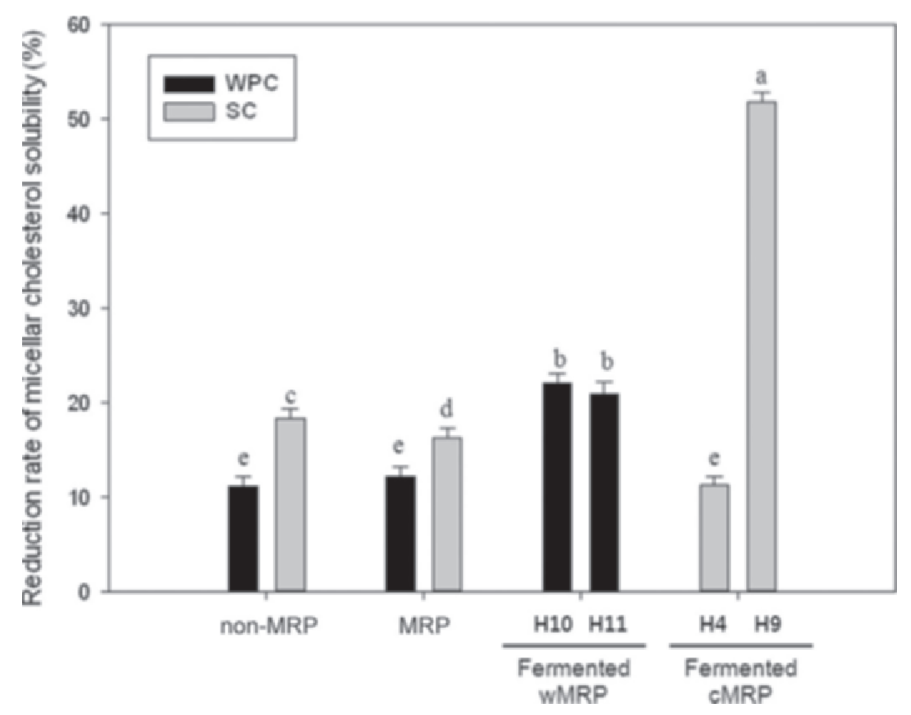

Figure 7. Hypocholesterolemic effect of (A) whey protein concentrate (WPC) and fermented Maillard-reacted WPC (wMRP), and (B) sodium caseinate (SC) and fermented Maillard-reacted SC (cMRP). Values are means $\pm \mathrm{SD}(\mathrm{n}=3)$; data followed by a different lowercase letter are significantly different $(P<0.05)$. 


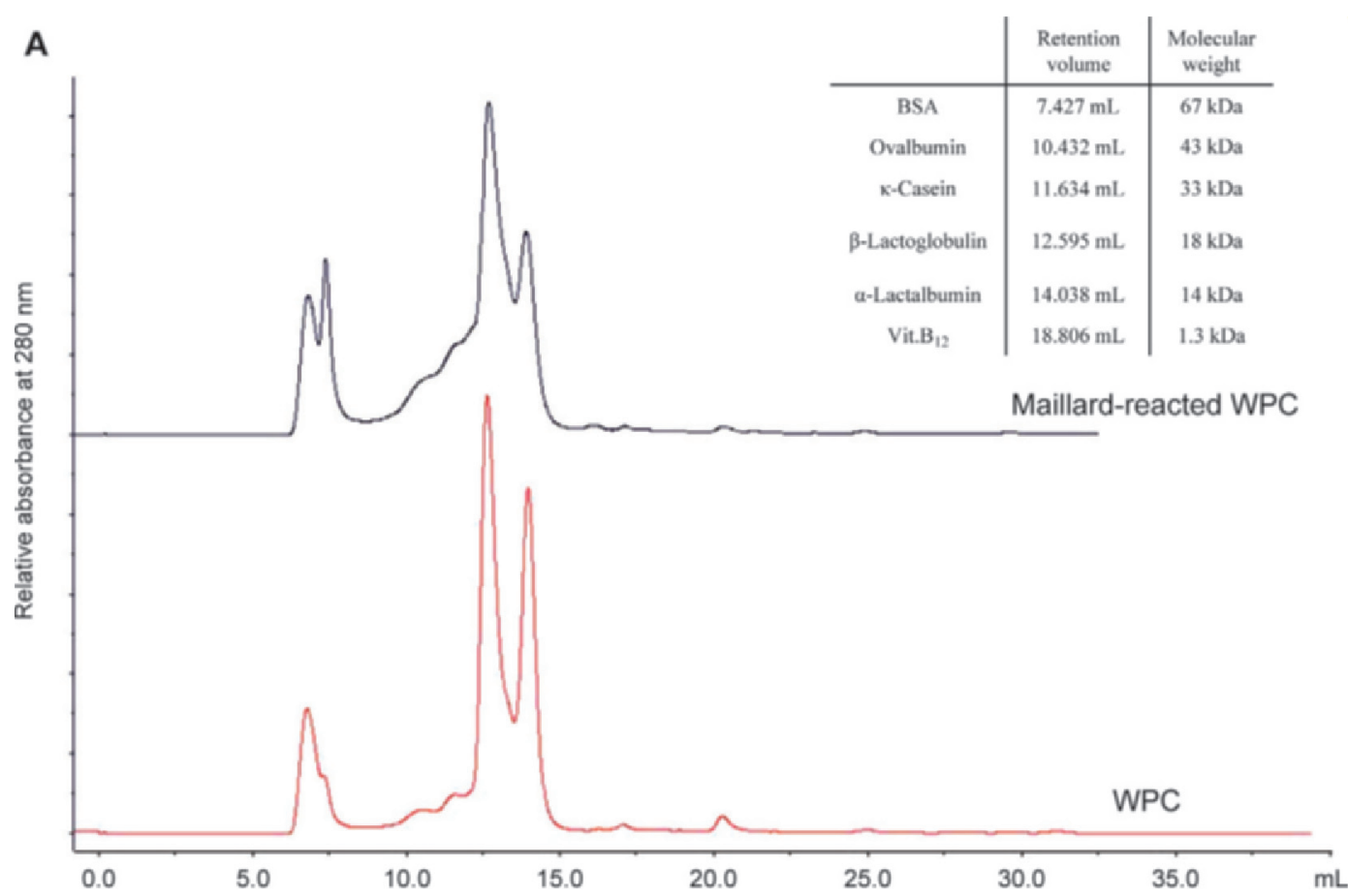

B

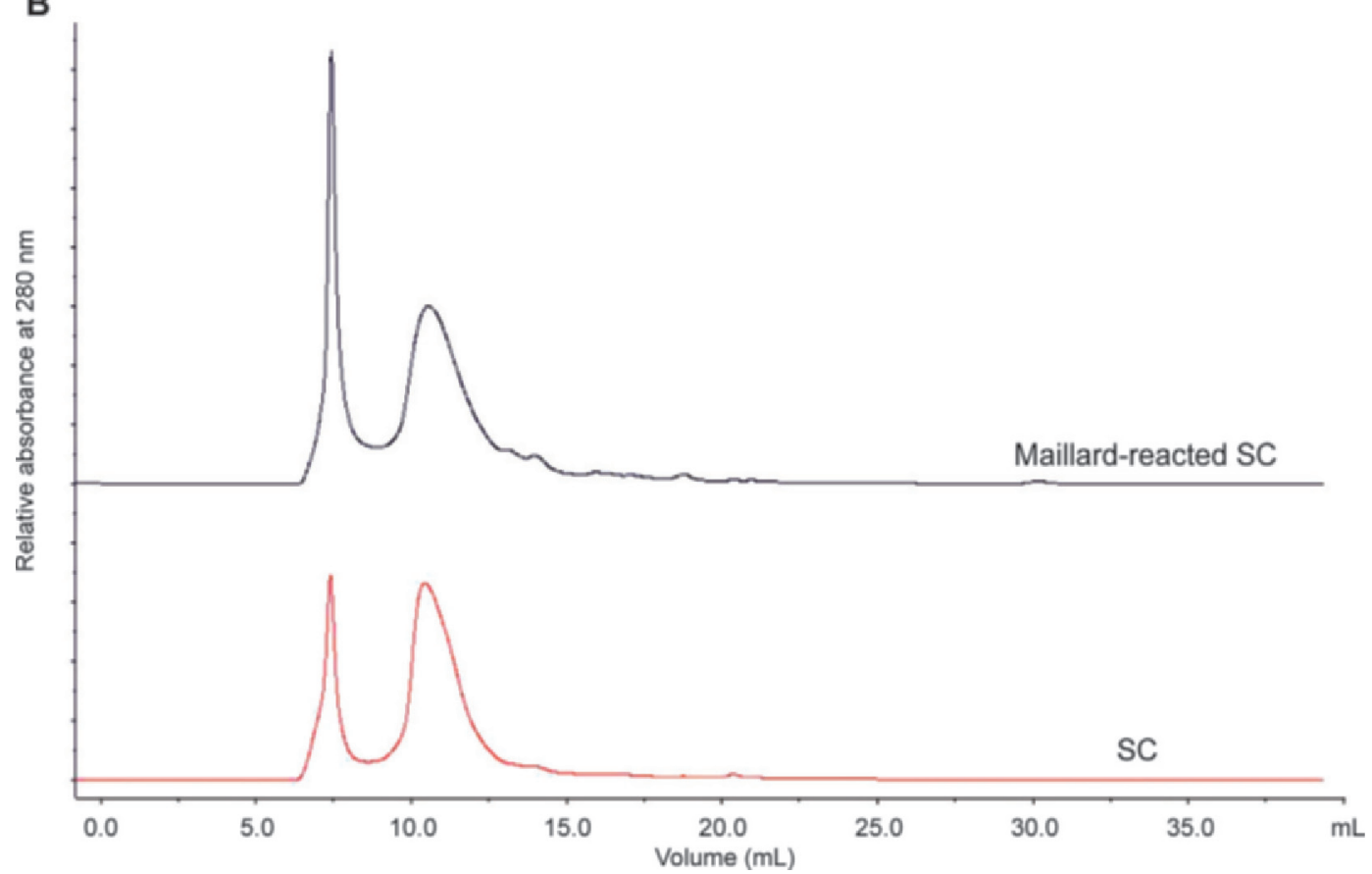

Figure 8. Chromatogram of (A) whey protein concentrate (WPC) and Maillard-reacted WPC (wMRP), and (B) sodium caseinate (SC) and Maillard-reacted SC (cMRP) obtained by size-exclusion chromatography by Superose 12 10/300 GL column (GE Healthcare Bio-Sciences AB, Björkgatan, Sweden). Color version available in the online PDF.

standing antioxidant, antithrombotic, HMGR inhibitory, and antihypercholesterolemic activities.

Several reports exist concerning the isolation by chromatography of food-derived bioactive peptides that have preventive cardiovascular effects. Pihlanto-
Leppälä et al. (1998) found that Thr-Thr-Met-Pro-LeuTrp from $\alpha_{S 1}$-casein had the highest ACE-inhibitory activity $\left(\mathrm{IC}_{50}\right.$ of $\left.51 \mu M\right)$, and Liu et al. (2010) purified an antioxidative peptide from porcine blood plasma protein that had an AA sequence of His-Asn-Gly-Asn. 


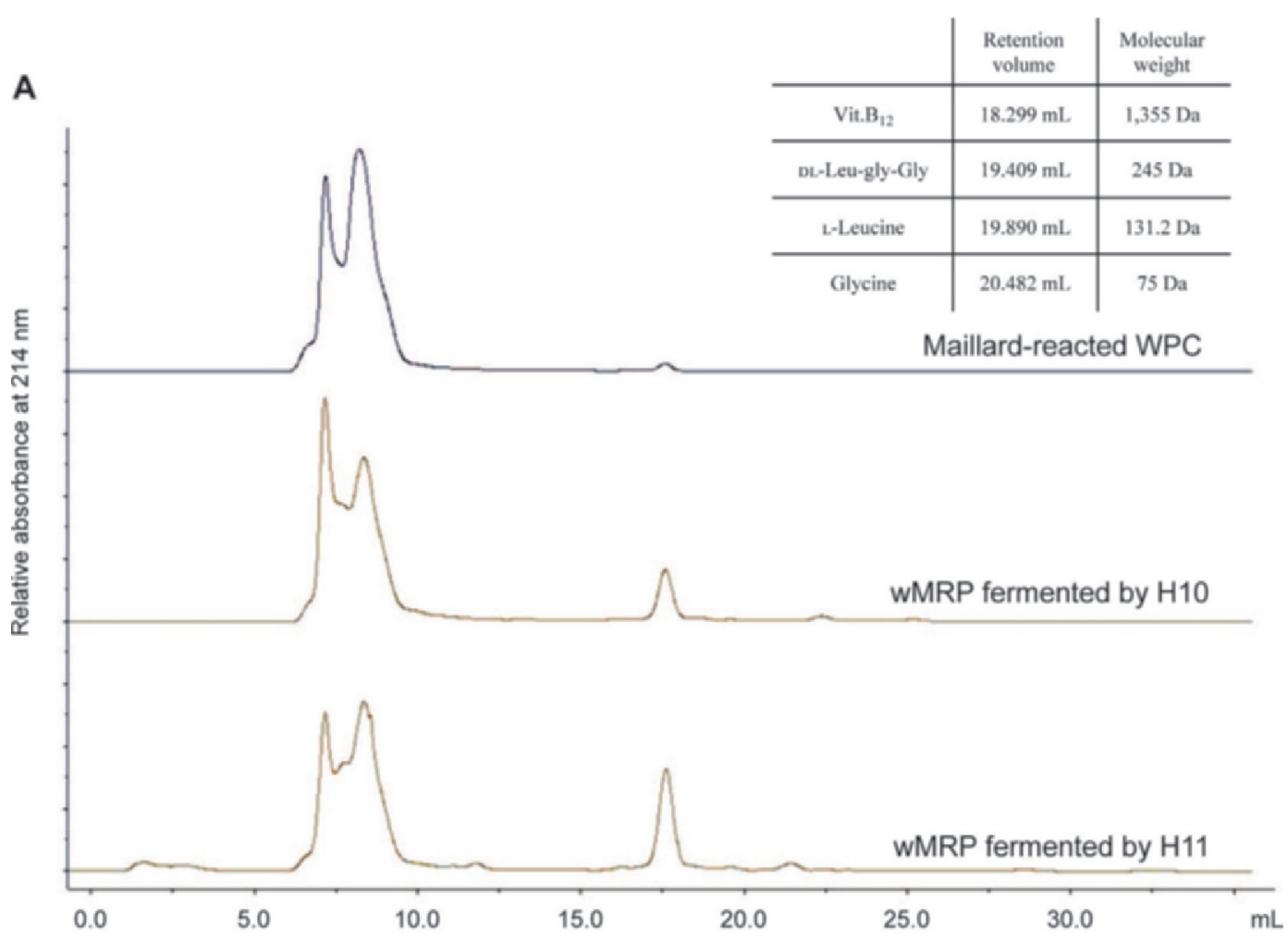

B

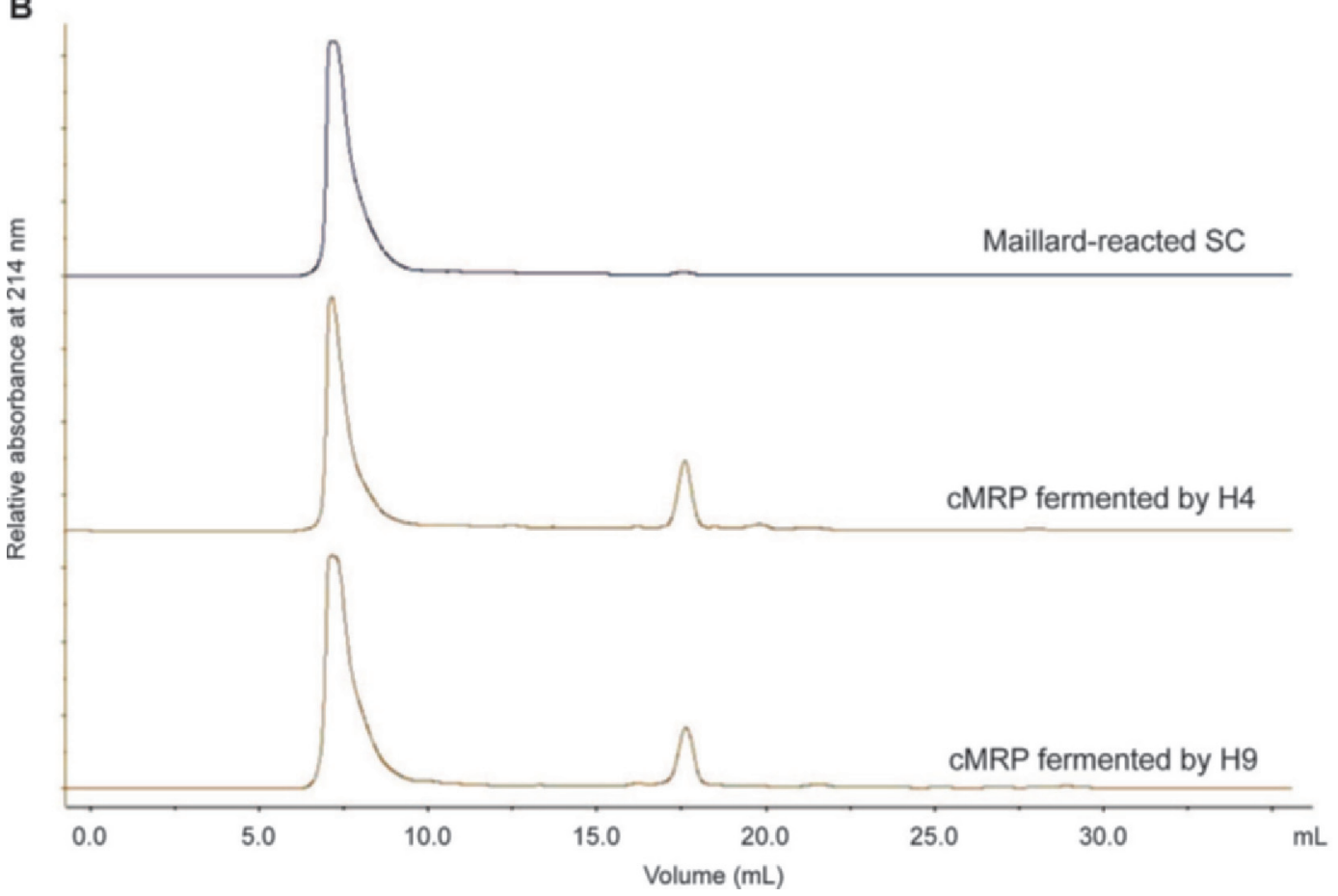

Figure 9. Chromatogram of (A) Maillard-reacted whey protein concentrate (WPC; wMRP) and fermented wMRP and (B) Maillard-reacted sodium caseinate (SC; cMRP) and fermented cMRP obtained by size-exclusion chromatography with a Superdex Peptide 10/300 GL column (GE Healthcare Bio-Sciences AB, Björkgatan, Sweden). Fermentation was by Lactobacillus gasseri (H10 and H11) and Lactobacillus fermentum (H4 and H9). Color version available in the online PDF. 
Huang et al. (2006) indicated that IIAEK (Ile-Ile-AlaGlu-Lys), named lactostatin, was isolated as a hypocholesterolemic peptide from $\beta$-LG in milk. However, different types of bioactive compounds other than peptides were hardly reported to be isolated for preventive cardiovascular effect.

\section{CONCLUSIONS}

Antioxidant properties (except for that measured by the DPPH assay) of milk proteins were enhanced by the Maillard reaction, and these activities gradually increased with fermentation time. The MRP showed higher levels of antithrombotic activity, HMGR inhibition, and reduction of micellar cholesterol solubility than did intact milk proteins; moreover, the functional properties of MRP were synergistically improved by fermentation. In particular, fermentation of wMRP by L. gasseri $\mathrm{H} 11$ and of cMRP by L. fermentum $\mathrm{H} 9$ had the greatest effect on overall preventive cardiovascular activity tests among 4 types of fermented MRP. Furthermore, we identified the production of small molecular-sized compounds from fermented MRP that probably had greater cardiovascular preventive effects than nonfermented MRP. Thus, fermented MRP could be used to reduce oxidative stress, platelet aggregation, cholesterol synthesis, and serum cholesterol levels for the reduction of cardiovascular risks in the pharmaceutical and dairy industries. Further studies are needed to isolate biological compounds from fermented MRP by diverse separation and purification systems and subsequently identify their sequences.

\section{ACKNOWLEDGMENTS}

This research was supported by the High ValueAdded Food Technology Development Program of the Korea Institute of Planning and Evaluation for Technology in Food, Agriculture, Forestry, and Fisheries (iPET, Gyeonggido, South Korea), and the Ministry for Food, Agriculture, Forestry, and Fisheries of Republic of Korea (Sejong Special Self-Governing City, South Korea; 111137-03-2-SB010).

\section{REFERENCES}

Aviram, M. 2000. Review of human studies on oxidative damage and antioxidant protection related to cardiovascular diseases. Free Radic. Res. 33(Suppl.):S85-S97.

Benzie, I. F., and J. Strain. 1996. The ferric reducing ability of plasma (FRAP) as a measure of "antioxidant power": The FRAP assay. Anal. Biochem. 239:70-76.

Blois, M. S. 1958. Antioxidant determinations by the use of a stable free radical. Nature 181:1199-1200.

Chen, Q., and R. A. Reimer. 2009. Dairy protein and leucine alter GLP-1 release and mRNA of genes involved in intestinal lipid metabolism in vitro. Nutrition 25:340-349.
Chevalier, F., J. M. Chobert, C. Genot, and T. Haertle. 2001. Scavenging of free radicals, antimicrobial, and cytotoxic activities of the Maillard reaction products of beta-lactoglobulin glycated with several sugars. J. Agric. Food Chem. 49:5031-5038.

Chobert, J. M., M. Z. Sitohy, and J. R. Whitaker. 1988. Solubility and emulsifying properties of caseins modified enzymatically by Staphylococcus aureus V8 protease. J. Agric. Food Chem. 36:220-224.

Chung, M. J., N. J. Sung, C. S. Park, D. K. Kweon, A. Mantovani, T. W. Moon, S. J. Lee, and K. H. Park. 2008. Antioxidative and hypocholesterolemic activities of water-soluble puerarin glycosides in HepG2 cells and in C57 BL/6J mice. Eur. J. Pharmacol. 578:159-170.

Coughlin, S. R. 1994. Thrombin receptor function and cardiovascular disease. Trends Cardiovasc. Med. 4:77-83.

Daniel, R. S., K. S. Devi, K. T. Augusti, and C. R. Sudhakaran Nair. 2003. Mechanism of action of antiatherogenic and related effects of Ficus bengalensis Linn. flavonoids in experimental animals. Indian J. Exp. Biol. 41:296-303.

Duangjai, A., K. Ingkaninan, S. Praputbut, and N. Limpeanchob. 2013. Black pepper and piperine reduce cholesterol uptake and enhance translocation of cholesterol transporter proteins. J. Nat. Med. 67:303-310.

Erdmann, K., B. W. Cheung, and H. Schröder. 2008. The possible roles of food-derived bioactive peptides in reducing the risk of cardiovascular disease. J. Nutr. Biochem. 19:643-654.

Fayle, S. E., and J. Gerrard. 2002. The Maillard Reaction. Vol. 5. Royal Society of Chemistry, Cambridge, UK

Fiat, A. M., S. Levy-Toledano, J. P. Caen, and P. Jollès. 1989. Biologically active peptides of casein and lactotransferrin implicated in platelet function. J. Dairy Res. 56:351-355.

Gobbetti, M., P. Ferranti, E. Smacchi, F. Goffredi, and F. Addeo. 2000. Production of angiotensin-I-converting-enzyme-inhibitory peptides in fermented milks started by Lactobacillus delbrueckii ssp. bulgaricus SS1 and Lactococcus lactis ssp. cremoris FT4. Appl. Environ. Microbiol. 66:3898-3904.

Gu, F., J. M. Kim, K. Hayat, S. Xia, B. Feng, and X. Zhang. 2009 Characteristics and antioxidant activity of ultrafiltrated Maillard reaction products from a casein-glucose model system. Food Chem. 117:48-54

Halliwell, B. 1994. Free radicals, antioxidants, and human disease: $\mathrm{Cu}-$ riosity, cause, or consequence? Lancet 344:721-724.

Houston, M. C. 2005. Nutraceuticals, vitamins, antioxidants, and minerals in the prevention and treatment of hypertension. Prog. Cardiovasc. Dis. 47:396-449.

Huang, Y.-S., Y. Yanagita, and H. R. Knapp, ed. 2006. Dietary Fats and Risk of Chronic Disease. AOCS Press, Champaign, IL.

Hwang, I. G., H. Y. Kim, K. S. Woo, J. Lee, and H. S. Jeong. 2011 Biological activities of Maillard reaction products (MRPs) in a sugar-amino acid model system. Food Chem. 126:221-227.

Iwami, K., K. Sakakibara, and F. Ibuki. 1986. Involvement of postdigestion 'hydrophobia' peptides in plasma cholesterol-lowering effect of dietary plant proteins. Agric. Biol. Chem. 50:1217-1222.

Jesch, E. D., J. M. Seo, T. P. Carr, and J. Y. Lee. 2009. Sitosterol reduces messenger RNA and protein expression levels of NiemannPick C1-like 1 in FHs 74 Int cells. Nutr. Res. 29:859-866.

Jollès, P. 1975. Structural aspects of the milk clotting process. Comparative features with the blood clotting process. Mol. Cell. Biochem. 7:73-85.

Kimoto, H., S. Ohmomo, and T. Okamoto. 2002. Cholesterol removal from media by lactococci. J. Dairy Sci. 85:3182-3188.

Kristinsson, H. G., and B. A. Rasco. 2000. Biochemical and functional properties of Atlantic salmon (Salmo salar) muscle proteins hydrolyzed with various alkaline proteases. J. Agric. Food Chem. 48:657-666.

Kritchevsky, D., S. A. Tepper, S. K. Czarnecki, and D. M. Klurfeld. 1982. Atherogenicity of animal and vegetable protein: Influence of the lysine to arginine ratio. Atherosclerosis 41:429-431.

Liu, Q., B. Kong, Y. L. Xiong, and X. Xia. 2010. Antioxidant activity and functional properties of porcine plasma protein hydrolysate as influenced by the degree of hydrolysis. Food Chem. 118:403-410. 
Livney, Y. D. 2010. Milk proteins as vehicles for bioactives. Curr. Opin. Colloids Interface Sci. 15:73-83.

Mazoyer, E., S. Lévy-Toledano, F. Rendu, L. Hermant, H. Lu, A. M. Fiat, P. Jollès, and J. Caen. 1990. KRDS, a new peptide derived from human lactotransferrin, inhibits platelet aggregation and release reaction. Eur. J. Biochem. 194:43-49.

McGookin, B. J., and M.-A. Augustin. 1991. Antioxidant activity of casein and Maillard reaction products from casein-sugar mixtures. J. Dairy Res. 58:313-320.

Megías, C., J. Pedroche, M. Del Mar Yust, M. Alaiz, J. Girón-Calle, F. Millán, and J. Vioque. 2009. Sunflower protein hydrolysates reduce cholesterol micellar solubility. Plant Foods Hum. Nutr. 64:86-93.

Mehrafarin, A., A. Qaderi, S. Rezazadeh, H. Naghdi Badi, G. Noormohammadi, and E. Zand. 2010. Bioengineering of important secondary metabolites and metabolic pathways in fenugreek (Trigonella foenum-graecum L.). J. Med. Plants 9:1-18.

Meisel, H. 1997. Biochemical properties of regulatory peptides derived from milk proteins. Biopolymers 43:119-128.

Meisel, H. 2005. Biochemical properties of peptides encrypted in bovine milk proteins. Curr. Med. Chem. 12:1905-1919.

Miguel, F., A. C. Augusto, and S. A. Gurgueira. 2009. Effect of acute vs chronic $\mathrm{H}_{2} \mathrm{O}_{2}$-induced oxidative stress on antioxidant enzyme activities. Free Radic. Res. 43:340-347.

Morales, F. J., and S. Jiménez-Pérez. 2001. Free radical scavenging capacity of Maillard reaction products as related to colour and fluorescence. Food Chem. 72:119-125.

Morita, T., A. Oh-hashi, K. Takei, M. Ikai, S. Kasaoka, and S. Kiriyama. 1997. Cholesterol-lowering effects of soybean, potato and rice proteins depend on their low methionine contents in rats fed a cholesterol-free purified diet. J. Nutr. 127:470-477.

Nagaoka, S., Y. Futamura, K. Miwa, T. Awano, K. Yamauchi, Y. Kanamaru, K. Tadashi, and T. Kuwata. 2001. Identification of novel hypocholesterolemic peptides derived from bovine milk $\beta$-lactoglobulin. Biochem. Biophys. Res. Commun. 281:11-17.

Ngamukote, S., K. Makynen, T. Thilawech, and S. Adisakwattana. 2011. Cholesterol-lowering activity of the major polyphenols in grape seed. Molecules 16:5054-5061.

Nielsen, P., D. Petersen, and C. Dambmann. 2001. Improved method for determining food protein degree of hydrolysis. J. Food Sci. 66:642-646.

Oh, N. S., H. Lee, J. Lee, J. Joung, K. Lee, Y. Kim, K. Lee, and S. Kim. 2013. The dual effects of Maillard reaction and enzymatic hydrolysis on the antioxidant activity of milk proteins. J. Dairy Sci. 96:4899-4911.

Pak, V., M. Koo, N. Lee, M. Kim, and D. Kwon. 2005. Structureactivity relationships of the peptide Ile-Ala-Val-Pro and its derivatives revealed using the semi-empirical AM1 method. Chem. Nat. Compd. 41:454-460.

Pihlanto-Leppälä, A. 2000. Bioactive peptides derived from bovine whey proteins: Opioid and ace-inhibitory peptides. Trends Food Sci. Technol. 11:347-356.

Pihlanto-Leppälä, A., T. Rokka, and H. Korhonen. 1998. Angiotensin I converting enzyme inhibitory peptides derived from bovine milk proteins. Int. Dairy J. 8:325-331.

Re, R., N. Pellegrini, A. Proteggente, A. Pannala, M. Yang, and C. Rice-Evans. 1999. Antioxidant activity applying an improved ABTS radical cation decolorization assay. Free Radic. Biol. Med. 26:1231-1237.

Rudel, L. L., and M. Morris. 1973. Determination of cholesterol using o-phthalaldehyde. J. Lipid Res. 14:364-366.

Sen, C. K. 1999. Glutathione homeostasis in response to exercise training and nutritional supplements. Mol. Cell. Biochem. 196:31-42.

Shihata, A., and N. Shah. 2000. Proteolytic profiles of yogurt and probiotic bacteria. Int. Dairy J. 10:401-408.

Silva, S. V., and F. X. Malcata. 2005. Caseins as source of bioactive peptides. Int. Dairy J. 15:1-15.

Smacchi, E., and M. Gobbetti. 2000. Bioactive peptides in dairy products: Synthesis and interaction with proteolytic enzymes. Food Microbiol. 17:129-141.

Tezcan, F., M. Gültekin-Özgüven, T. Diken, B. Özçelik, and F. B. Erim. 2009. Antioxidant activity and total phenolic, organic acid and sugar content in commercial pomegranate juices. Food Chem. 115:873-877.

Usenik, V., J. Fabčič, and F. Štampar. 2008. Sugars, organic acids, phenolic composition and antioxidant activity of sweet cherry (Prunus avium L.). Food Chem. 107:185-192.

Yang, W. G., Z. Wang, and S. Y. Xu. 2007. A new method for determination of antithrombotic activity of egg white protein hydrolysate by microplate reader. Chin. Chem. Lett. 18:449-451.

Zhong, F., J. Liu, J. Ma, and C. F. Shoemaker. 2007. Preparation of hypocholesterol peptides from soy protein and their hypocholesterolemic effect in mice. Food Res. Int. 40:661-667. 